\title{
Detailed hydrogeomorphic analysis in the Gerecse Mountains, Hungary
}

\author{
Edina JÓZSA \\ Doctoral School of Earth Sciences, University of Pécs, Hungary \\ e-mail: edina.j0zs4@gmail.com
}

Manuscript received Sept. 15, 2016; revised Sept. 29, 2016; Accepted Oct. 7, 2016

\begin{abstract}
The northern foreland of the Central Gerecse Mountains is a complex landscape with a moderate relief and the presence of terrace remnants. To explore the hydrogeomorphic settings, the characteristics of the drainage network, several basin metrics, and geomorphometric maps were interpreted, which are the outputs of a semi-automated algorithm. Based on the results, the small catchments of the area were divided into two groups with diverse topographic characteristics and the presence of 7 terrace levels was revealed.
\end{abstract}

Keywords: geomorphometry, DEM, semi-automated landform mapping, fluvial geomorphology, GRASS GIS, R

\section{Introduction}

Exploring the evolution of fluvial landscapes by analysing the hydrogeomorphic signatures of the topography has interested many Hungarian geomorphologists since the $19^{\text {th }}$ century $[1,2,3,4,5]$. As significant watercourses of the hilly and mountainous ranges of the Pannonian Basin are accompanied by terrace remnants, the key to understand the development of the Danube valley and its tributaries is to compile a scientific synthesis of the terrace system [2, 3]. The complex geomorphological and geological settings require objective and detailed mapping projects to distinguish between landforms of different origin and recognize the effects of neotectonics.

During the past decades, new data sources and terrain-analysing tools led to novel opportunities in earth sciences and geomorphometry is now one of the most prosperous subdivisions of modern geomorphology [6]. Deriving morphometric parameters and interpreting the resulting maps has become a common practice to explore the geological [7], topographical [8], and hydrological [9] characteristics of 
a given area. Furthermore, GIS-based algorithms have proved to be suitable for the paleo-profile reconstruction and mapping of terrace remnants as well [10].

The wider environment of the study site is thoroughly studied in the geologic and geomorphologic literature in Hungary. The main topics relevant for the current study are the terrace levels of the Danube valley $[2,11]$, the travertines $[3,12]$, and the mass movements [13] in the region.

The aim of this study was to carry out a detailed DEM-based morphometric analysis of a small area in the Gerecse Mountains. Due to the complex evolution of the region, it is challenging to draw conclusions about the topographic configuration using only traditional geomorphological research methods. The compiled semi-automated algorithm allows the objective mapping of the hydrogeomorphic characteristics with low time and cost requirements. Exploring the spatial pattern and anomalies of the stream network and delineating landforms, especially terrace remnants, provide new insights into the landscape. The new results obtained with this unified procedure can be integrated with former researches about the surface development. As mentioned above, the area has a wide literature, and thus the GIS-based results can be compared to findings of previous studies and the available geomorphological map.

Table 1. Terrace levels in the Gerecse Mountains according to Pécsi, M. (1959)

\begin{tabular}{|c|c|c|c|c|c|c|c|c|c|c|c|}
\hline \multirow{2}{*}{$\begin{array}{c}\text { Right bank } \\
\text { settlement }\end{array}$} & \multirow{2}{*}{$\begin{array}{c}\text { Distance } \\
\text { from } \\
\text { mouth } \\
(\mathbf{k m})\end{array}$} & \multirow{2}{*}{$\begin{array}{c}\text { 0 level of } \\
\text { Danube } \\
(\mathrm{m} \\
\text { a.b.s.l. })\end{array}$} & \multicolumn{9}{|c|}{ m above Danube level } \\
\hline & & & \begin{tabular}{|l|} 
FLP \\
(low) \\
\end{tabular} & I & II/a & II $/ \mathbf{b}$ & III & IV & $\mathbf{V}$ & VI & VII \\
\hline Szöny & 1,753 & 103.18 & & 5 & 10 & 23 & & 78 & & & \\
\hline Dunaalmás & 1,751 & 103.13 & 3 & 5 & 10 & 27 & 47 & 78 & 120 & 170 & 210 \\
\hline Neszmély & 1,749 & 103.05 & 3 & 5 & 9 & 22 & 37 & 72 & 120 & 150 & 210 \\
\hline Süttő & 1,743 & 102.58 & & & 8 & & 43 & & & 170 & 170 \\
\hline Lábatlan & 1,737 & 102.11 & 3 & 5 & 7 & & & 72 & & 160 & 200 \\
\hline Nyergesújfalu & 1,733 & 101.95 & & 5 & 9 & 20 & 46 & 68 & & 140 & 170 \\
\hline Tát & 1,727 & 101.61 & & & & & & 80 & & & \\
\hline Esztergom & 1,718 & 100.92 & 2.5 & 6 & 10 & 18 & 48 & 78 & & & \\
\hline
\end{tabular}

Over the more than 100 years of the Hungarian terrace-morphological researches, there has not been a satisfactory synthesis of the spatial arrangement and chronology of the terrace levels. The most widely accepted terrace system for the Hungarian stretch of the Danube valley was published by Pécsi, M. in 1959 (Table 1). As these results involve a number of uncertainties due to the demanding field work and lack of detailed geomorphological maps, the overview of the Danube valley and its tributaries with suspected terraces using DEM-based, quantitative surface analysis algorithm could provide new insights into the topic. 


\section{Legend}

$\square$ study area settlements

- streams $\square$ microregions
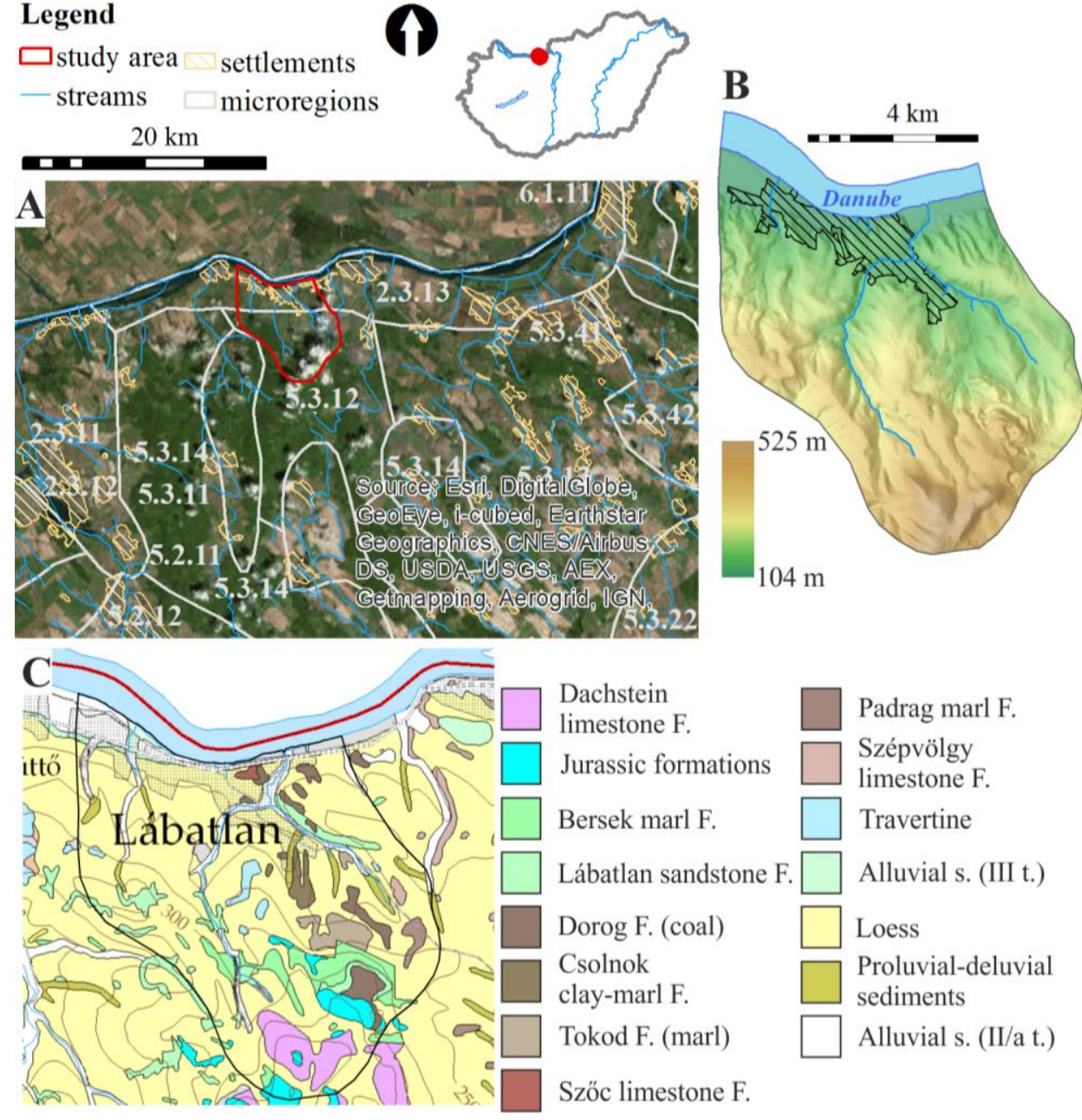

Dachstein limestone F. Jurassic formations Bersek marl F. Lábatlan sandstone F.

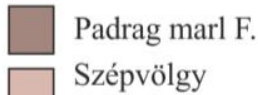
limestone F. Travertine Dorog F. (coal) Csolnok clay-marl F. Tokod F. (marl)

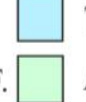
Alluvial s. (III t.) Szőc limestone F.

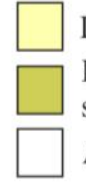
Loess Proluvial-deluvial sediments Alluvial s. (II/a t.)

Figure 1. Location (A), topography (B), and geology (C) of the study area. (Source of geological map: http://map.mfgi.hu/fdt100/)

The studied area is located on the northern slopes of the Gerecse Mountains, in Northern Transdanubia, along the Hungarian-Slovakian border (Fig. 1). The $25 \mathrm{~km}^{2}$ region comprises several small catchments directly draining to the Danube. The area belongs to the Central Gerecse Mountains (5.3.12 on Fig. 1A) and the Almás-Tát Danube Valley (2.3.13 on Fig. 1A) microregions [14]. The 0 level of the Danube varies between $103.88 \mathrm{~m}$ (at Komárom) and $100.92 \mathrm{~m}$ (at Esztergom). The minimum 
elevations are found on the lower floodplain level from $104 \mathrm{~m}$, while the highest peak is the Nagy-Eménkes with $525 \mathrm{~m}$. For the presented study, the catchment area of Piszke, Fuchs, and Lábatlan streams was selected.

The mountain is mostly built up of well-karstified Triassic and Jurassic limestones, while the majority of the surface is covered by Quaternary clastic sediments and alluvial materials [15]. The loess and travertine deposits have a great importance for the terrace chronology $[3,16]$.

From a geomorphological point of view, the area can be divided into two distinct landscape types. Under $150 \mathrm{~m}$ a.s.l., the undulating surface is the terraced valley slope of the Danube. The northern foreland of the Gerecse Mountains is the first section in Hungary where the river has a defined, antecedent valley. The low mountainous area is well-dissected, it comprises a series of horsts, while its slopes are also characterized by the landforms of fossil and recent mass movements. The stream network has a general $\mathrm{S}-\mathrm{N}$ flow direction though some valley sections reflect the influence of neotectonics.

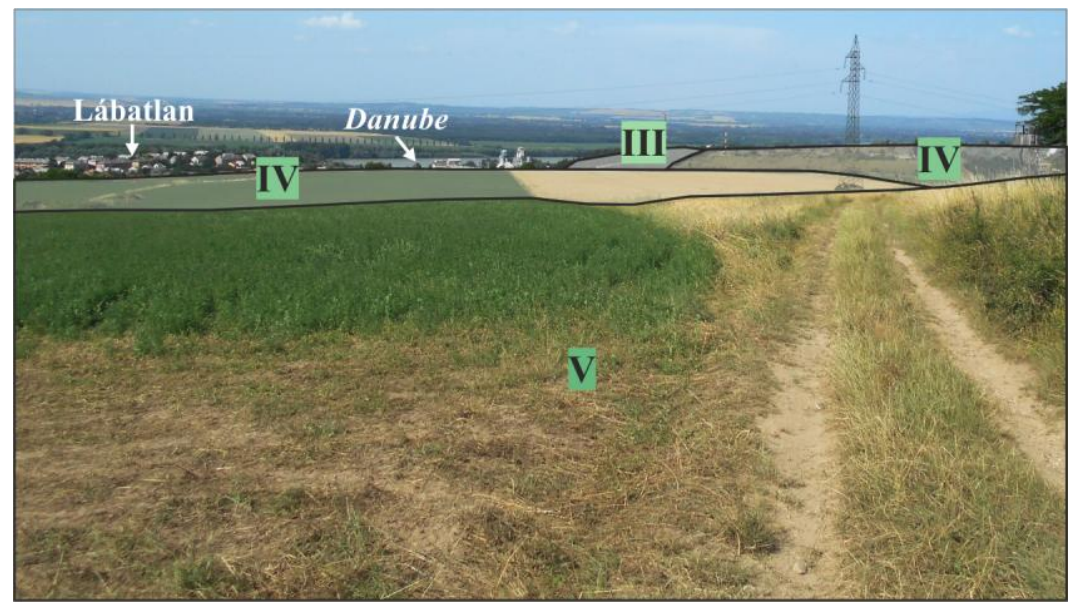

Figure 2. Terrace levels in the study area (Photo by author, 2016)

Terrace researches identified the presence of up to 7-8 terrace levels in this marginal zone of the Transdanubian Range [2]. Several authors [1, 2, 11] reported the occurrence of multiple terrace surfaces in Lábatlan and its surroundings, which were also well recognizable during the field survey (Fig. 2). 


\section{Materials and methods}

Research objectives required a high-resolution digital elevation model to create detailed maps of the hydrogeomorphic parameters. The terrain analysis was based on a contour-based DEM with $5 \mathrm{~m}$ horizontal resolution, distributed by FÖMI (National Institute of Geodesy, Cartography and Remote Sensing). Based on previous research by the author [17] and considering the price and quality of the available DEMs for Hungary, it is highly recommended to purchase contour lines dataset from FÖMI and interpolate hydrologically correct models for catchment analyses. Geological and geomorphological map on a 1:100,000 scale, auxiliary information from literature, and field survey were also analysed to interpret and validate the GIS-based results.

Table 2. List of generated morphometric parameters

\begin{tabular}{ccc}
\hline Parameters & Description & Tools \\
\hline topographic grain & characteristic ridgeline - valley bottom & distance \\
\hline slope, aspect & basic topographic derivatives & r.slope.aspect \\
\hline $\begin{array}{c}\text { relative relief, } \\
\text { slope variability }\end{array}$ & $\begin{array}{c}\text { range of elevation and slope values } \\
\text { calculated per unit area }\end{array}$ & r.neighbors \\
\hline $\begin{array}{c}\text { stream/valley } \\
\text { network }\end{array}$ & $\begin{array}{c}\text { map of streams/valleys based on flow } \\
\text { accumulation }\end{array}$ & $\begin{array}{c}\text { r.threshold, } \\
\text { r.stream.extract }\end{array}$ \\
\hline $\begin{array}{c}\text { length-direction } \\
\text { plot }\end{array}$ & general direction of valley network & r.stream.segment \\
\hline $\begin{array}{c}\text { normalized long } \\
\text { profile }\end{array}$ & $\begin{array}{c}\text { comparable plot of longitudinal profile }- \text { it } \\
\text { indicates differences in valley development }\end{array}$ & $\begin{array}{c}\text { r.stream.order, } \\
\text { r.stream.distance }\end{array}$ \\
\hline $\begin{array}{c}\text { hypsometry } \\
\text { it indicates differences in surface evolution }\end{array}$ & r.stream.basins \\
\hline basin metrics & shape indices of catchment & r.basin \\
\hline $\begin{array}{c}\text { landform } \\
\text { elements }\end{array}$ & $\begin{array}{c}\text { geomorphometric map of the 10 most } \\
\text { common landforms }\end{array}$ & r.geomorphon \\
\hline $\begin{array}{c}\text { terrace-like } \\
\text { surfaces }\end{array}$ & plots and map of possible terrace remnants & script by author \\
\hline
\end{tabular}

GIS techniques provided the opportunity to analyse the different catchments in a consequent and comparable way. Table 2 gives a summary of the generated morphometric parameters and the necessary tools to create the maps. The selected methods are mostly part of the r.stream.* hydrological GRASS GIS module by [9]. The R statistical software was used for the calculation of several indices and the display of diagrams (ggplot2 package). A more detailed description of the methods is given with the resulting maps presented. 
It is important to emphasize that all steps were carried out using GNU GPL (General Public License), open-source software including GRASS GIS 7.0.3 (http://grass.osgeo.org) to create and process the maps and R (http://r-project.org) to perform the statistical analyses.

\section{Results and discussions}

The quantitative analysis of the topographic configuration started with the definition of the so-called topographic grain value, which refers to the characteristic ridgeline-to-valley bottom distance [18]. As the search window has a great influence on the scale and characteristics of the generated morphometric parameters, the topographic grain value was used for neighbourhood size parameter in the GIS-based terrain analysis. The calculation of the topographic grain is implemented as a bash shell script for GRASS GIS and R. By calculating the relative relief values with nested neighbourhood matrices, it is possible to define a break-point where the increase rate of local relief encountered by the sample is significantly reducing. The results suggested $310 \mathrm{~m}$ as the topographic grain value, which was used later to calculate the relative relief and slope variability per unit area and to create the landform map of the study site.

The spatial variability of the relief energy and the slope values (Fig. 3) suggests a lower, gently sloping region, where the terrace surfaces and the settlement are located, while the higher region is characterized by the flat horst top surfaces surrounded by steep slopes and deeply cut valleys. The highest relative relief and slope values are found around the open-pit mine. Furthermore, as the surroundings of the mine are covered by loess, the high relief is also a result of mass movements.
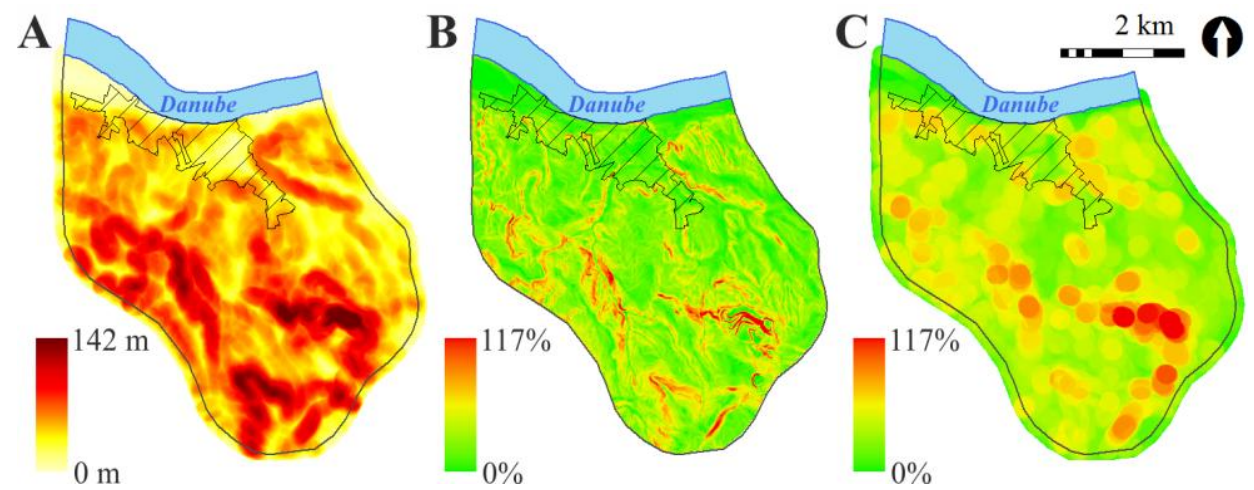

Figure 3. Relative relief (A), slope (B), and slope variability (C) map 
The derivation of the stream network was completely based on the DEM data. The drainage area suggested by the software is $0.035 \mathrm{~km}^{2}$, without considering the geology or the climatic conditions in the area; thus, the result is rather interpreted as the extended valley network. The generated map and the length-azimuth rose diagram (Fig. 4) visually and numerically confirm that the typical valley orientation is SSE-NNW, S-N.

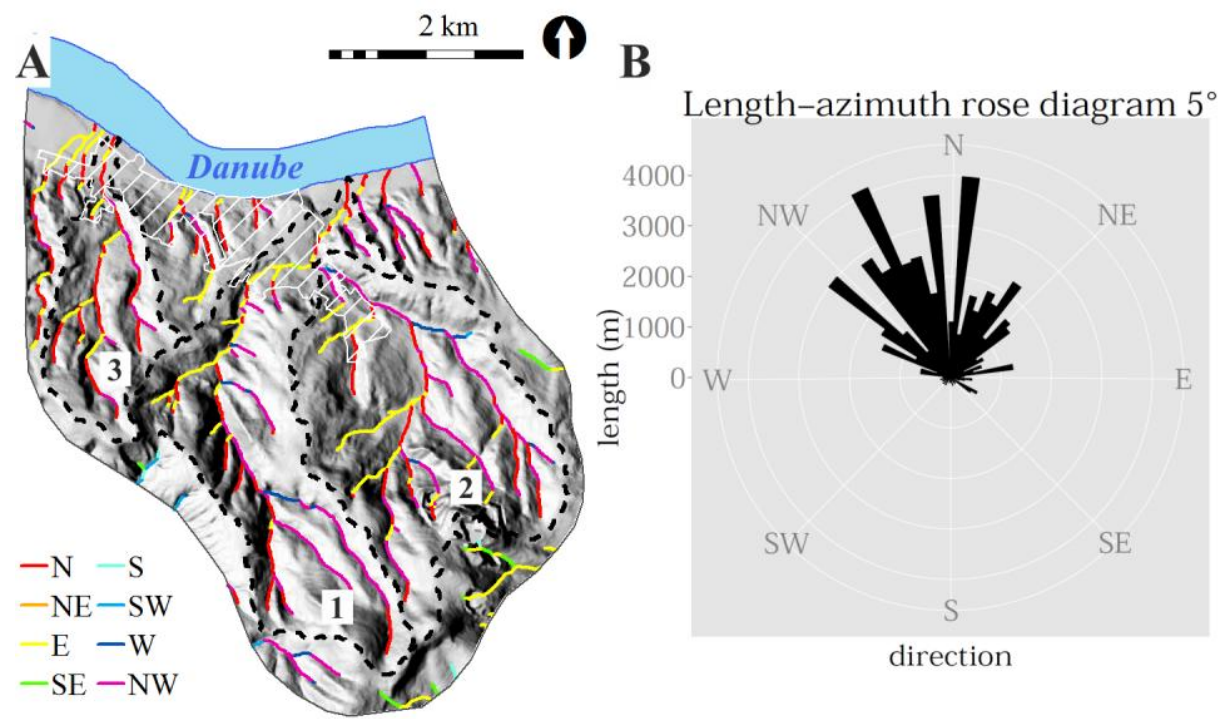

Figure 4. Valley network and area of catchments (A), length-azimuth rose diagram (B) [1 Lábatlan stream basin, 2 - Fuchs stream basin, 3 - Piszke stream basin]

The direct comparison of the analysed 3 streams was accomplished by generating the dimensionless normalized longitudinal profiles and calculating concavity parameters. They can highlight the effects of lithological changes and tectonic events on the valley development $[8,19]$. The profiles and concavity values show a strong similarity between the Lábatlan and Piszke streams. The maximum concavity is modest, reaches close to the midpoint of the watercourses, suggesting that these streams have a less graded profile. Deviations of the Fuchs stream can be explained by topographic characteristics (slope break at pediment), lithological changes, and the tectonically predicted lower valley section. As a result, there is a significant break on the Fuchs stream and its valley has an asymmetric shape on the lower sections. 

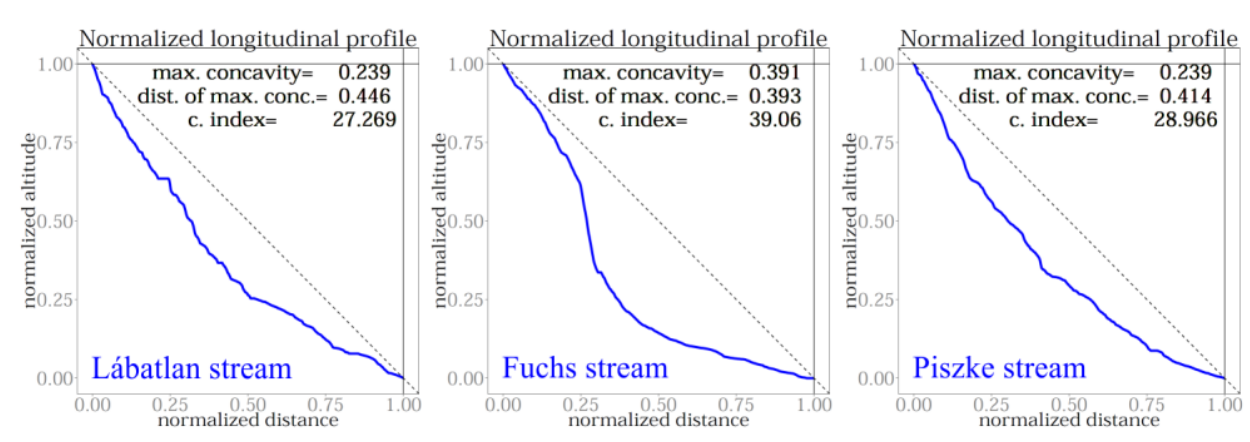

Figure 5. Normalized longitudinal profiles.

Several parameters were calculated for the analysis of the selected basins (Table 3). The hypsometric curve and integral (Ihyp) enabled the comparison of the elevation distribution, thus providing auxiliary information about the stage of landscape evolution and the dominant geomorphic processes $[8,18]$. The elevation distribution confirms the presence of terrace-like surfaces, as overrepresented altitude values occur on the plots. The higher values of the hypsometric integral suggest a well-dissected area, while the lower value is representative for low relief with extensive flat regions.

Table 3. Basin metrics of the analysed small catchments

\begin{tabular}{l|c|c|c}
\hline & $\begin{array}{c}\text { Lábatlan } \\
\text { stream basin }\end{array}$ & $\begin{array}{c}\text { Fuchs stream } \\
\text { basin }\end{array}$ & $\begin{array}{c}\text { Piszke stream } \\
\text { basin }\end{array}$ \\
\hline Ihyp & 0.408 & 0.297 & 0.480 \\
Catchment area & $5.3 \mathrm{~km}^{2}$ & $6.4 \mathrm{~km}^{2}$ & $2.3 \mathrm{~km}^{2}$ \\
Elevation difference & $396.9 \mathrm{~m}$ & $368.5 \mathrm{~m}$ & $255.3 \mathrm{~m}$ \\
Length of main channel & $6.0 \mathrm{~km}$ & $4.9 \mathrm{~km}$ & $3.5 \mathrm{~km}$ \\
Elongation ratio & 0.43 & 0.62 & 0.49 \\
Shape factor & 0.88 & 1.38 & 0.67 \\
\hline
\end{tabular}

Analysing the basin metrics was also part of the research; the calculation was easily feasible with the r.basin add-on specifically developed for this purpose [20]. The basins of the Lábatlan and Piszke stream are more elongated and, accordingly, the possibility of the formation of higher-order tributaries is low [21]. The Fuchs stream shows different characteristics in this case as well, as it has an important right-bank tributary.

The GIS-based geomorphological map of the study area was created by the geomorphons approach, a robust cell-based method for the identification of landform elements at a broad range of scales by using line-of-sight-based neighbourhoods [22]. The characteristics of the geomorphons map depend on the 
value of lookup distance defining the maximum scale of mapping, the skip radius to eliminate forms that are too small to be of interest, and the flatness threshold to prevent the analysis of flat areas. The topographic grain value was selected as lookup distance parameter, while other parameters were chosen to fit the basic rules of the geomorphological mapping concepts adopted in Hungary. The resulting map (Fig. $6 B$ ) shows strong similarity to the traditional geomorphological map (Fig. 6A), the valley networks are mostly coherent, and the landforms are not generalized.

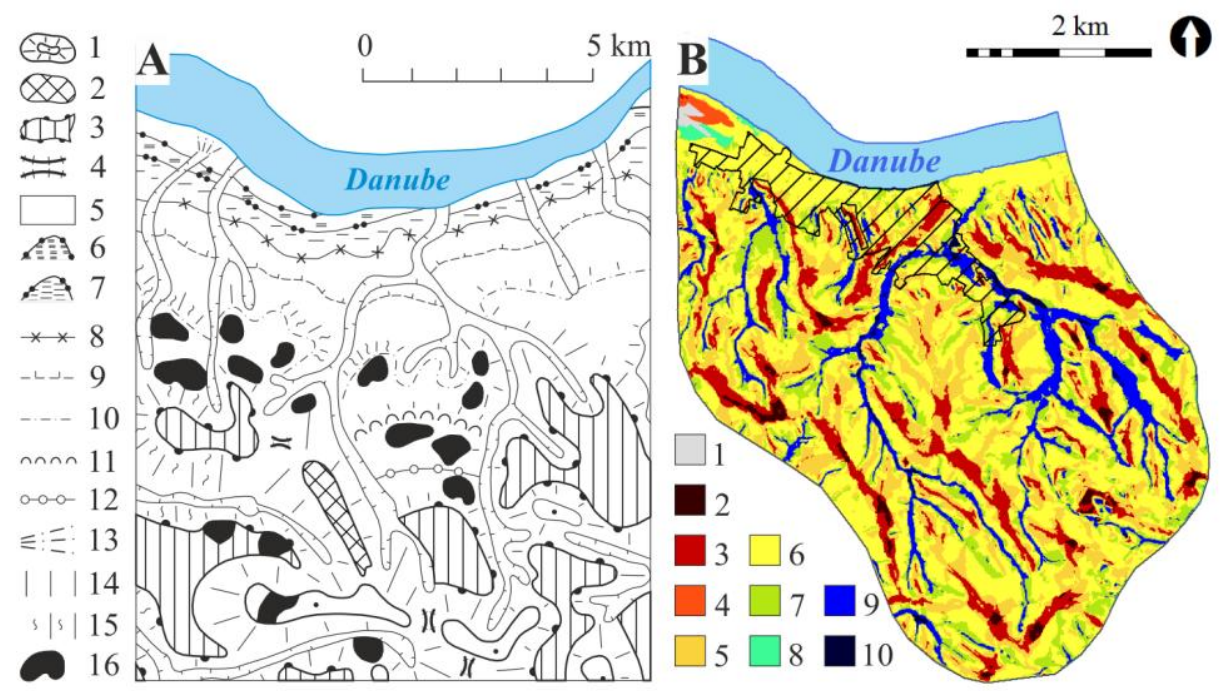

Figure 6. Geomorphological map after Pécsi, M. - Schweitzer, F. [1980] (A) and geomorphometric map (B). [Legend A: 1 - horst, 2 - ridge, 3 - pediment, 4 - saddle, 5 - low floodplain, 6 - II/a terrace, 7 - II/b terrace, 8 - III. terrace, $9-\mathrm{IV}$. terrace, $10-\mathrm{V}$. terrace, 11 - VI. terrace, 12 - VII. terrace, 13 - alluvial fan, 14 - stable slope,

15 - temporarily stable slope, 16 - travertine; Legend B: 1 - flat, 2 - summit, 3 - ridge, 4 - shoulder, 5 - spur, 6 - slope, 7 - hollow, 8 - foot-slope, 9 - valley, 10 - depression]

The GIS-based terrace mapping methodology largely builds on the work of [10]. Further improvements of the method were carried out in the form of an $\mathrm{R}$ script using GRASS GIS functionality. The algorithm cuts up the studied area into parallel sections in the flow direction and determines cells potentially belonging to terrace surfaces based on local slope characteristics. The output report contains a histogram of altitudes, a swath-profile of the landscape (Fig. 7A), scatter plots to represent the relation of the relative elevation and slope values, and a final plot showing the longitudinal profile of the river with the determined height ranges of 
terrace levels. The algorithm also produces a raster map containing the cells of terrace top-surfaces (Fig. 7B).

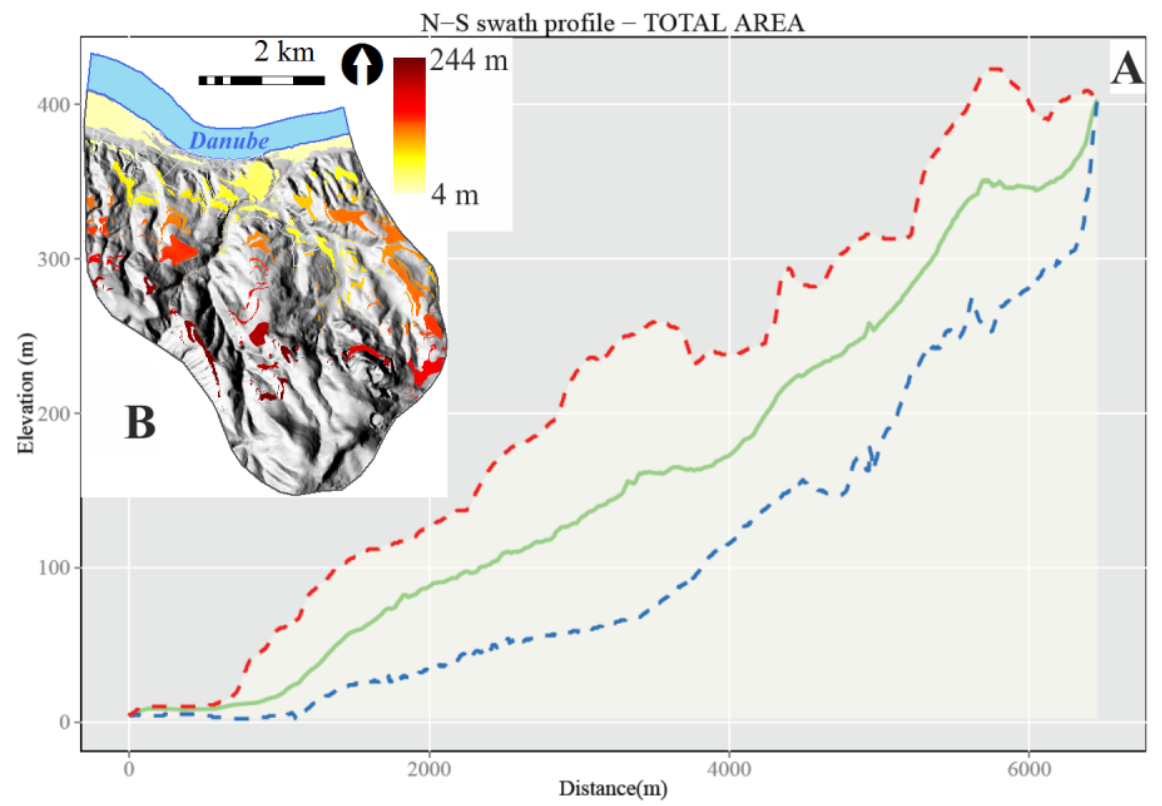

Figure 7. Swath profile (A) and map of terrace-like surfaces (B). [Legend A: blue minimum curve, green - mean curve, red - maximum curve]

On the minimum and maximum curve of the swath-profile, multiple flat regions can be observed, not only in the lower elevations. The map of terrace-like surfaces is in good agreement with the geomorphological map (Fig. 6A), although in some cases the method selected cells belonging to pediment surfaces as well. In the central section of the map, terrace-top surfaces shown on the photo above (Fig. 2) can also be identified. Based on the results produced by the compiled algorithm, 7 terrace levels could be distinguished, similar to the findings of $[2,16]$. However, the altitude ranges of the terrace levels differ with 5-10 meters from the values defined by M. Pécsi, especially in the case of higher terrace levels.

\section{Conclusions}

The current study explored the potentials of the novel DEM-based geomorphological research, on the example of the detailed hydrogeomorphic analysis of a small study area in the Transdanubian Range. The selected morphometric parameters provided objective and quantifiable information on the 
topographic configuration and the spatial pattern of hydrological network; therefore, they are useful to reveal insights into landscape evolution.

Based on the analysed parameters, the small catchments could be divided into two categories. The Fuchs stream basin shows different characteristics in every aspect, which can be explained mainly by the geological conditions and it is clearly visible in the appearance of the landforms as well.

The methodological assessment of the selected open-source software was also an important part of the study. Both the GRASS GIS and R proved to be suitable to compile a semi-automated algorithm for such a detailed geomorphic research. The scripts developed for the computation of the topographic grain value and the delineation of terrace-like surfaces are also considered as significant scientific output.

The presented work is a good example that the joint analysis of a wide range of morphometric parameters can reveal new information even in well-studied regions by producing objective, reproducible, and comparable results.

\section{Acknowledgements}

The author would like to express her gratitude for the colleagues of the Department of Physical and Environmental Geography for the professional advice on the study and the support of the Doctoral School of Earth Sciences, University of Pécs. The present scientific contribution is dedicated to the $650^{\text {th }}$ anniversary of the foundation of the University of Pécs.

This research was supported by the Human Capacities Grant Management Office and the Hungarian Ministry of Human Capacities in the framework of the NTP-NFTÖ-16 project.

\section{References}

[1] Bulla, B. (1941), A magyar medence pliocén és pleisztocén teraszai (Pliocene and Pleistocene terraces of the Hungarian Basin). Földrajzi Közlemények 69(4), 199-230.

[2] Pécsi, M. (1959), A magyarországi Duna-völgy kialakulása és felszínalaktana (Development and geomorphology of the Hungarian Danube Valley), vol 3. Földrajzi Kiadó, Budapest, Hungary.

[3] Gábris, Gy. Nádor, A. (2007), Long-term fluvial archives in Hungary: response of the Danube and Tisza rivers to tectonic movements and climatic changes during the Quaternary: a review and new synthesis. Quaternary Science Reviews 26, 2758-2782.

[4] Bugya, T. (2009), Identification of Quaternary fluvial terraces using borehole data and digital elevation models. Zeitschrift für Geomorphologie, Supplementbände 53(2), 113-121.

[5] Szeberényi, J., Viczián, I., Fábián, Sz. Á., Józsa, S. (2013), The relation of the South-Eastern Börzsön Hills to the Visegrad Gorge, Hungary. Studia Geomorphologica Carpatho-Balcanica 47(1), 81-93. 
[6] Seijmonsbergen, A. C., Hengl, T., Anders, N. S. (2011), Semi-automated identification and extraction of geomorphological features using digital elevation data. In: Smith, M. J., Paron, P., Griffiths, J. (eds), Geomorphological mapping: a professional handbook of techniques and applications, 24. Developments in Earth Surface Processes, Elsevier, Amsterdam, Netherlands, 298-330.

[7] Grohmann, C. H., Riccomini, C., Alves, F. M. (2007), SRTM-based morphotectonic analysis of the Pocos de Caldas Alkaline Massif, south-eastern Brazil. Computers \& Geosciences 33, 10 19.

[8] Ruszkiczay-Rüdiger, Zs., Fodor, L., Horváth, E., Telbisz, T. (2009), Discrimination of fluvial, eolian and neotectonic features in a low hilly landscape: A DEM-based morphotectonic analysis in the Central Pannonian Basin, Hungary. Geomorphology 104, $203-217$.

[9] Jasiewicz, J., Metz, M. (2011), A new GRAS GIS toolkit for Hortonian analysis of drainage networks. Computers \& Geosciences 37, 1162-1173.

[10] Demoulin, A., Bovy, B., Rixhon, G., Cornet, Y. (2007), An automated method to extract fluvial terraces from digital elevation models: The Vesdre Valley, a case study in eastern Belgium. Geomorphology 91(1-2), 51-64.

[11] Kéz, A. (1934), A Duna győr-budapesti szakaszának kialakulásáról (On the development of the Danube Valley between Györ and Budapest). Földrajzi Közlemények 62(10-12), 175-193.

[12] Scheuer, Gy., Schweitzer, F. (1988), A Gerecse- és a Budai-hegység édesvízi mészkőösszletei (The travertines of Gerecse and Buda Mountains). Akadémiai Kiadó, Budapest, Hungary.

[13] Ádám, L., Schweitzer, F. (1985), A Neszmély-Dunaalmás-Dunaszentmiklós közötti felszínmozgásos terület 1:10.000-es méretarányú geomorfológiai térképének magyarázója (Explanatory study for the 1:10,000-scale geomorphological map of the Neszmély-DunaalmásDunaszentmiklós mass movement region). In: Ádám, L., Pécsi, M. (eds), Mérnökgeomorfológiai térképezés (Engineering geomorphological mapping). Hungarian Academy of Sciences, Geographical Research Institute, Budapest, Hungary, 108-167.

[14] Dövényi, Z. (ed.) (2010), Magyarország kistájainak katasztere (Inventory of microregions in Hungary). Magyar Tudományos Akadémia, Csillagászati és Földtudományi Kutatóintézet, Budapest, Hungary.

[15] Schweitzer, F. (1980), Gerecse-hegység (Gerecse Mountains). In: Ádám, L., Marosi, S., Szilárd, J. (eds), A Dunántúli-középhegység - Regionális tájföldrajz (The Transdanubian Range - Regional geography). Akadémiai Kiadó, Budapest, Hungary, 369-380.

[16] Pécsi, M. (1991), Geomorfológia és domborzatminősítés (Geomorphology and terrain analysis). Magyar Tudományos Akadémia, Földrajzi Kutatóintézet, Budapest, 121-139.

[17] Józsa, E., Fábián, Sz. Á., Varga, G., Varga, T. (2014), Meredek lejtőkkel elválasztott sík felszínek domborzatmodellezésének sajátosságai dunai magaspartok példáján (The possibilities for digital elevation modelling of plains connected with steep slopes on the example of the high bluffs of the Danube). Modern Geográfia 9(2), 1-20.

[18] Pike, R. J., Wilson, S. E. (1971), Elevation-relief ratio, hypsometric integral, and geomorphic area-altitude analysis. Geological Society of America Bulletin 82(4), 1079-1084.

[19] Demoulin, A. (1998), Testing the tectonic significance of some parameters of longitudinal river profiles: the case of the Ardenne (Belgium, NW Europe). Geomorphology 24(1-2), 189-208.

[20] Di Leo, M. (2010), Working report: extraction of morphometric parameters from a digital elevation model - Panama. North Carolina State University.

[21] Horton, R. E. (1932), Drainage-basin characteristics. Eos Trans AGU 13(1), 350-361.

[22] Jasiewicz, J., Stepinski, T. (2013), Geomorphons - a pattern recognition approach to classification and mapping of landforms. Geomorphology 182, 147-156. 